\title{
ヒアリの毒性成分とその作用 ヒアリの毒とは?
}

\section{真壁秀文}

信州大学大学院総合理工学研究科

筆者の専門は有機合成化学である．長年天然有機化合物の 合成を手がけてきた。15年ほど前から立体選択的な2,6-ピペ リジン環の合成方法を検討し, ピペリジンアルカロイドの合 成へ展開していた，その研究の過程で2,6-シス-ピペリジン環 であるイソソレノプシンという化合物の合成を達成した，イ ソソレノプシンの由来はどこか調べてみると "fire ant”（Solenopsis invicta, 和名はヒアリ) から単離されているという ことであった ${ }^{(1)}$.ヒアリとういう言葉の意味は, このアリは赤 色であることと，刺されたときに火傷をしたような激しい痛 みを感じるからである、イソソレノプシンの合成を達成した のは2016年の秋であった ${ }^{(2)}$. 当時は，なぜアリからこのよう なアルカロイドが単離されているのか不思議に思った程度で, まさかすぐに社会問題になるとは夢にも思わなかった ${ }^{(3)}$.

ヒアリは，2017年5月 26 日に兵庫県尼崎市で貨物船に運 ばれたコンテナから見つかって以来，6都道府県で計 8 回発 見されている. 福岡県では作業員がヒアリに腕を刺されて軽 傷を負い，日本国内で初めて人的被害が出た．幸いなことに いずれからも，ヒアリが繁殖し，定着しているという報告は なかった。ヒアリの原産地はブラジルであり，1930年代に は米国で確認され，貨物の輸送などが盛んになるにつれ，そ の後ニュージーランド，オーストラリア，中国，台湾などに 侵入し定着している. 米国ではヒアリが侵入している地域で 半数以上の住民が刺された経験があり, 毎年 1,400 万人以上

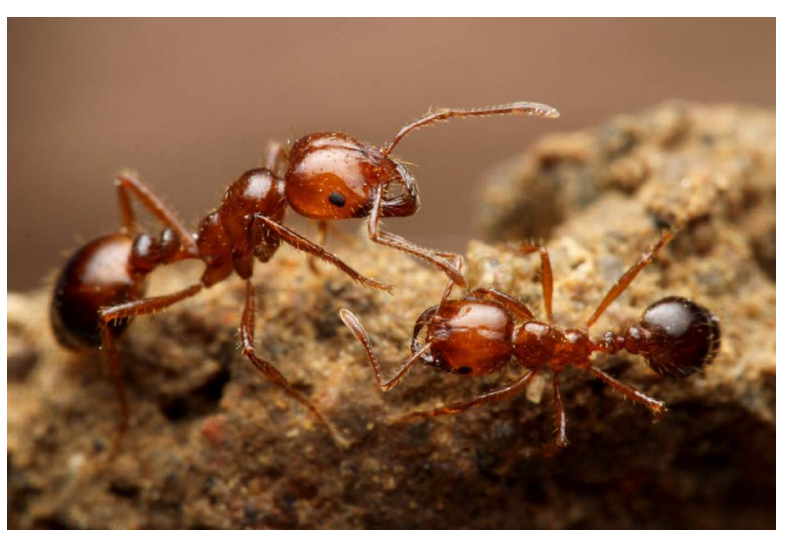

図1・台湾産のヒアリ

AntRoom 島田拓氏ご提供.
もの人々が被害に遭い 100 名弱が死亡しているものと推定さ れている(4). 死因はアナフィラキシーショックとされてい る。また，オーストラリア，中国，台湾でも多数の刺傷例が 報告されており，中国では死亡例も出ている．現代は物流が 盛んになりたいへん便利な世の中になっているが，その分危 険な外来生物は侵入しやすくなって扔り，対策が急務となっ ている(図1).

ヒアリは殺人アリともいわれている. なぜ危険なのか. 本稿ではヒアリの毒性成分に関して解説する.

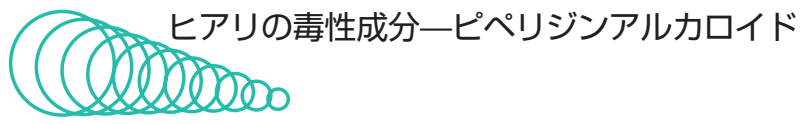

ヒアリの毒性成分は 2,6-二置換ピペリジンアルカロイドと され，毒液の $95 \%$ を占めている.アルカロイドとは「アル カリに似た物質」という意味で, 当初は生理活性を有する塩 基性の植物由来の成分のことを指していた。しかしその後, 塩基性を示さない化合物も見いだされるようになり，今日で は窒素原子を含む天然有機化合物で一次代謝産物以外の物質 をアルカロイドと呼んでいる(5).アルカロイドは, 微量で動 物の神経系に作用して種々の生理活性を示すことから, 研究 者の注目を集めてきた。そして，しばしば毒性を示すことが ある，有名な例は，アルカロイドを毒として利用する生物の ヤドクガエルである，ヤドクガエルは，生息地を同じくする アリやダニなどからアルカロイドを摂取して体内に貯える. 一方，ヒアリは自分の体の中で生合成することができる．獲 物の捕獲や防衛のために使用するため，アリにとって非常に 重要な役割を担っている. ヒアリがもつアルカロイドの総称 はソレノプシンだが，有機合成化学者は 2 位と 6 位がトラン ス体のものはソレノプシン, シス体ではイソソレノプシンと 呼んでいる，立体異性体であるがシス体に比べてトランス体 のほうがかなり含有率が高い。これらの化合物は 2 位にはメ チル基，6位には不飽和結合を含むさまざまなアルキル基を もっている. なかでもソレノプシン A は心肺機能の低下を 引き起こすと言われている(6). そのメカニズムは，一酸化窒 素合成酵素の作用を妨げることで神経間のアセチルコリン伝 達ができなくなることである(7).ただし，ヒアリに刺されて もごく微量の毒素しか体内には侵入しないため, 直ちに重篤 
な症状にはならないと考えられるが，多数のヒアリに刺され た場合は注意が必要である（図2）。

ヒアリがもつアルカロイドは侵入地で多様化しているこ とが報告されている．2位の側鎖に存在するアルキル基は C11, C13，C15は知られていたが，最近になって C17が発見 された ${ }^{(8)}$.アルキル側鎖とピペリジン環内に二重結合が存在 する化合物も報告されている。 さらに環状イミンも同定され て抢り，ポリケチド骨格由来のアルカロイドの生合成中間体 にも環状イミンが見られることから，ヒアリがもつアルカロ イドは体内で生合成されていると考えられる（図3）.

ピペリジン環の 2 位と 6 位に存在する置換基の立体化学と, 6位の側鎖の長さおよび側鎖に含まれている二重結合の幾何 異性体を考虑に入れると，ヒアリの毒性成分は非常に多様性<smiles>[R]C1CCC[C@@H](C)N1</smiles>

solenopsin 2,6-trans<smiles>[R]C1CCC[C@@H](C)N1</smiles>

isosolenopsin 2,6 -cis
R (saturated) $=\mathrm{C}_{11} \mathrm{H}_{23}, \mathrm{C}_{13} \mathrm{H}_{27}, \mathrm{C}_{15} \mathrm{H}_{31}, \mathrm{C}_{17} \mathrm{H}_{35}$ (unsaturated) $=\mathrm{C}_{11} \mathrm{H}_{21}, \mathrm{C}_{13} \mathrm{H}_{25}, \mathrm{C}_{15} \mathrm{H}_{29}, \mathrm{C}_{17} \mathrm{H}_{33}$

$$
\mathrm{R}=\mathrm{C}_{11} \mathrm{H}_{23}: \text { solenopsin } \mathrm{A}
$$

図2ロソレノプシンとイソソレノプシンの構造
に富んでいることがわかる。なおソレノプシンの絶対立体配 置は1994年にBraekman らによって報告され, ソレノプシン $\mathrm{A}$ では $(2 R, 6 R)$ と決定された ${ }^{(9)}$. 近年, ヒアリより同定さ れた2,6-二置換ピペリジンアルカロイドを図4に示す ${ }^{(8)}$.

上述のアルカロイド類は主にGC-MSで同定されている. それぞれ構造が類似しているため各々の化合物の分離は困難 と思われる。また，個々の化合物の毒性の評価などまだまだ 不明なことが多い，さらに，ピペリジンアルカロイドの存在 比は種によって異なっている，毒性の評価をするうえで純粋 なサンプルのある程度の量的確保は必須である。この課題を 解決するためには有機合成の力が必要である，筆者は長年パ ラジウム触媒を用いたピペリジン環の構築を行ってきた。こ の研究の過程で 2,6-二置換ピペリジン環の効率的な合成法を 確立し，ヒアリの毒性成分であるイソソレノプシンを塩酸塩 の形で合成することができた，本合成法ではクロスメタセシ ス反応などを駆使して異なる長さの側鎖を導入することも可 能であり, 毒性への影響を調べることができる（図5（2).

また，最近ではトランス型の 2,6 -二置換ピペリジン環の構 築を急いでいる．なぜならばヒアリの毒性成分はトランス型 のほうが毒性が強いとされているからである．現在のところ 図6のようにトランス：シスが約 $1: 1$ の比でピペリジン環を 得ている ${ }^{(10)}$. 今後は触媒の配位子を検討し, トランス選択 的なピペリジン環の合成を目指すことにしている。サンプル の量的確保が可能になれば, 分子レベルでの毒性発現のメカ ニズムの解明が進むであろう。
$\mathrm{H}_{3} \mathrm{C}$<smiles>CPC1CCC[C@H](N)P1</smiles><smiles>C1CCCC1</smiles><smiles>C1CCCCC1</smiles>

trans 2,6-piperidine<smiles>CCCC1CCCC1C</smiles>

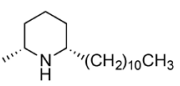<smiles>[R]C1CCC[C@@H](C)N1</smiles><smiles>[R]C1CCC[C@@H](C)N1</smiles>

図3ロソレノプシンの推定されている生合成経路 ${ }^{(9)}$<smiles>CCC1CCCC1</smiles><smiles>CCCC1CCCN1</smiles>

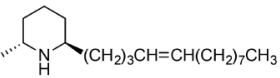

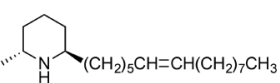

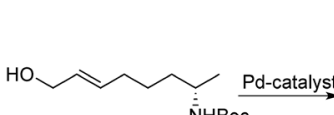
$\overline{\mathrm{N}} \mathrm{HBoc}$

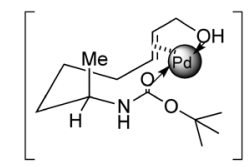

cross-metathesis<smiles>CCCCCCCC</smiles><smiles>CCC1CCC(C)N1</smiles>

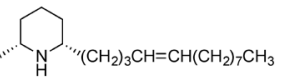

cyclic imine<smiles>CCCCCCCCCC</smiles><smiles>CCCCCCCCCCC</smiles><smiles>CCCC1CCCCC1</smiles>

$\widehat{\mathrm{N}}_{\left(\mathrm{CH}_{25} \mathrm{CH}=\mathrm{CH}\left(\mathrm{CH}_{2}\right)_{7} \mathrm{CH}_{3}\right.}$

図4ロヒアリより同定されたピペリジンア ルカロイド

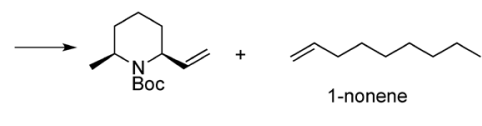

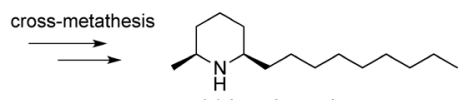

$(-)$-isosolenopsin

図5ロ(-)-イソソレノプシンの合成 


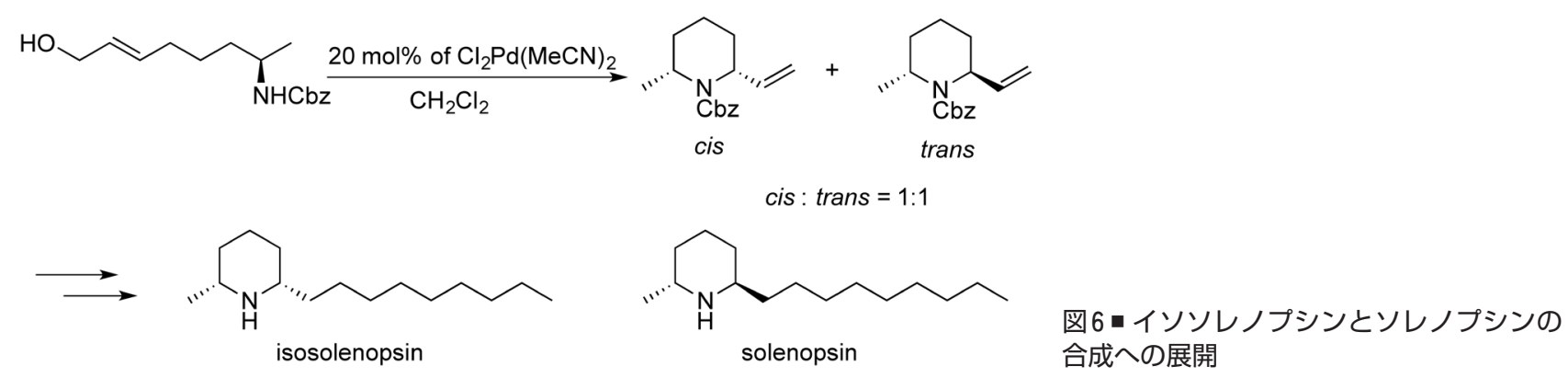

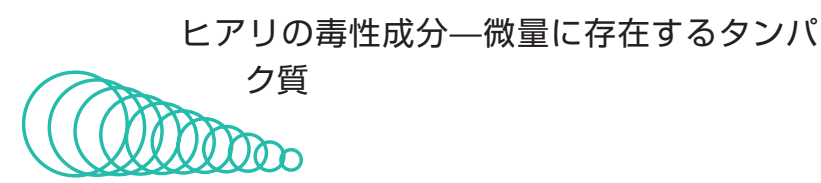

一方, 最近Palmaらの研究によると, ヒアリの毒素には 46 種類のタンパク質がごく微量に存在することが明らかに された ${ }^{(11)}$. Palmaらはこれらのタンパク質のプロテオーム解 析を行った。この 46 種類のタンパク質の役割には以下の分 類が提唱されている. (1) self-venom protection (2) colony asepsis (3)chemical communication (4) proteins influencing the homeostasis of the victims (5) neurotoxins (6) proteins that promote venom diffusion (7) proteins that cause tissue damage and inflammation (8)allergens上記のタンパク質の うち(4)〜8は有害と考えられる. 特にヒアリの毒により激し いアナフィラキシーショックを発症し, 命を落とすケースも 報告されていることから，8のアレルギーを引き起こすタン パク質には注意が必要である。今後はこれらのタンパク質の 機能解析により, アレルギー発症のメカニズムが分子レベル で解明され，対策が進んでいくと考えられる.

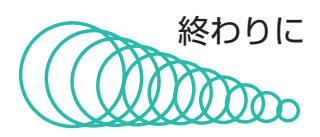

現代は世界中で人や物資が行き来する時代である。した がって, 外来種の侵入や定着を完全に封じ込めるのは不可能 に近いと考えられる。しかし，それが人間や家畜に被害を与 えるものであったり，生態系や環境を著しく破壊し経済的に かなりのダメージを与えたりする場合は，防御態勢を整えて おくことが重要である.

本稿では，このヒアリの毒素ついて化学の視点から正し い知識を身につけて, 将来へ備えるとともに, 冷静な対応が できるように解説した. 少しでも多くの方々へ参考になって いただければ幸いである。

\section{文献}

1) T. H. Jpnes, M. S. Blum \& H. M. Fales: Tetrahedron, 38, 1949 (1982).

2) Y. Takemoto, Y. Hattori \& H. Makabe: Heterocycles, $\mathbf{9 4}$, 286 (2017).

3) 村上貴弘：現代化学, 558, 44 (2017).

4) R. D. deShazo, D. F. Williams \& E. S. Moak: Ann. Intern. Med., 131, 424 (1999).

5) 貫名 学, 星野 力, 木村靖夫, 夏目雅裕：“生物有機化 学”, 三共出版, 2012, p. 205.

6) G. Howell, J. Butler, R. D. deShazo, J. M. Fareley, H. L. Liu, N. P. Nanayakkara, A. Yates, G. B. Yi \& R. W. Rockhold: Ann. Allergy Asthma Immunol., 94, 380 (2005).

7) G. B. Yi, D. Mc Clendon, D. Desaiah, J. Goddard, A. Lister, J. Moffitt, R. K. Vander Meer, R. de Shazo, K. S. Lee \& R. W. Rockhold: Int. J. Toxicol., 22, 81 (2003).

8) Y. T. Yu, H. Y. Wei, H. Y. Fadamiro \& L. Chen: J. Agric. Food Chem., 62, 5907 (2012).

9) S. Leclerq, I. Thirrionet, F. Broeders, D. Daloze, R. Van der Meer \& J. C. Braeckman: Tetrahedron, 50, 9333 (1994).

10) M. Asai, Y. Takemoto, A. Deguchi, Y. Hattori \& H. Makabe: Tetrahedron Asymmetry, 28, 1582 (2017).

11) J. R. A. dos Santos Pinto, E. G. P. Fox, D. M. Saidemberg, L. D. Santos, A. R. da Silva Mengasso, E. Costa-Manso, E. A. Machado, O. C. Bueno \& M. S. Palma: J. Proteome Res., 11, 4643 (2012).

プロフィール

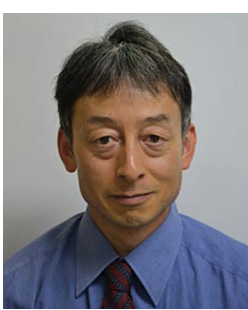

真壁 秀文 (Hidefumi MAKABE)

<略歴>1992年東北大学農学部農芸化学 科卒業／1994年同大学大学院農学研究科 農芸化学専攻博士課程前期修了／1997年 同大学大学院農学研究科農芸化学専攻博 士課程後期修了, 博士 (農学) /同年日本 学術振興会海外特別研究員 (米国Purdue 大学) $/ 1999$ 年同大学農学部応用生命科学 科助手 / 2001 年同大学大学院農学研究科 機能性食料開発学専攻助教授 $/ 2007$ 年同 大学大学院農学研究科機能性食料開発学 専攻准教授 / 2011 年同大学大学院農学研 究科機能性食料開発学専攻教授 / 2017 年 同大学大学院総合理工学研究科農学専攻 食品生命科学分野教授, 現在に至る<研 究テーマと抱負 >生理活性天然物の合成, 有機金属化学を用いた新規反応の開発 <趣味>風景写真, 信州の山歩き<所属 研究室ホームページ>http://www.shinshu-u.ac.jp/faculty/agriculture/overview/ labo/l-function/post-8.ph

Copyright (C) 2018 公益社団法人日本農芸化学会 DOI: 10.1271/kagakutoseibutsu.56.513 